\title{
Rainfall-runoff modelling and palaeoflood hydrology applied to reconstruct centennial scale records of flooding and aquifer recharge in ungauged ephemeral rivers
}

\author{
G. Benito $^{1}$, B. A. Botero ${ }^{2,}$, V. R. Thorndycraft ${ }^{3}$, M. Rico ${ }^{4}$, Y. Sánchez-Moya ${ }^{5}$, A. Sopeña ${ }^{5}$, M. J. Machado ${ }^{1}$, and \\ O. Dahan ${ }^{6}$ \\ ${ }^{1}$ Museo Nacional de Ciencias Naturales, CSIC, Serrano 115bis, 28006 Madrid, Spain \\ ${ }^{2}$ Department of Civil Engineering, Universidad Nacional de Colombia sede Manizales, Manizales, Colombia \\ ${ }^{3}$ Department of Geography, Royal Holloway University of London, Egham, Surrey TW20 0EX, UK \\ ${ }^{4}$ Pyrenean Institute of Ecology, CSIC, Avda. Montañana 1005, 50059 Zaragoza, Spain \\ ${ }^{5}$ Institute of Geosciences, CSIC-Universidad Complutense, 28040, Madrid, Spain \\ ${ }^{6}$ Zuckerberg Institute for Water Research, Ben-Gurion University of the Negev, Sde Boqer, 84990, Israel \\ *current address: Facultad de Ingenierías, Universidad de Medellín, Medellín, Colombia
}

Received: 26 November 2010 - Published in Hydrol. Earth Syst. Sci. Discuss.: 21 December 2010

Revised: 21 March 2011 - Accepted: 28 March 2011 - Published: 8 April 2011

\begin{abstract}
In this study we propose a multi-source data approach for quantifying long-term flooding and aquifer recharge in ungauged ephemeral rivers. The methodology is applied to the Buffels River, at $9000 \mathrm{~km}^{2}$ the largest ephemeral river in Namaqualand (NW South Africa), a region with scarce stream flow records limiting research investigating hydrological response to global change. Daily discharge and annual flood series (1965-2006) were estimated from a distributed rainfall-runoff hydrological model (TETIS) using rainfall gauge records located within the catchment. The model was calibrated and validated with data collected during a two year monitoring programme (20052006) at two stream flow stations, one each in the upper and lower reaches of the catchment. In addition to the modelled flow records, non-systematic flood data were reconstructed using both sedimentary and documentary evidence. The palaeoflood record identified at least 25 large floods during the last $700 \mathrm{yr}$; with the largest floods reaching a minimum discharge of $255 \mathrm{~m}^{3} \mathrm{~s}^{-1}$ ( $450 \mathrm{yr}$ return period) in the upper basin, and $510 \mathrm{~m}^{3} \mathrm{~s}^{-1}$ (100 yr return period) in the lower catchment. Since AD 1925, the flood hydrology of the Buffels River has been characterised by a decrease in the magnitude and frequency of extreme floods, with palaeoflood discharges (period 1500-1921) five times greater than the largest modelled floods during the period 1965-2006. Large
\end{abstract}

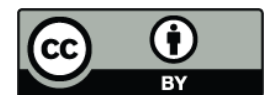

Correspondence to: G. Benito (benito@ccma.csic.es) floods generated the highest hydrograph volumes, however their contribution to aquifer recharge is limited as this depends on other factors such as flood duration and storage capacity of the unsaturated zone prior to the flood. Floods having average return intervals of 5-10 $\mathrm{yr}\left(120-140 \mathrm{~m}^{3} \mathrm{~s}^{-1}\right)$ and flowing for 12 days are able to fully saturate the Spektakel aquifer in the lower Buffels River basin. Alluvial aquifer storage capacity limiting potential recharge by the largest floods is a common problem in arid environments, with the largest infiltration volumes favoured by increasing depth to groundwater levels.

\section{Introduction}

Ephemeral rivers are characterised by an intermittent hydrology, dominated by flood and drought episodes, which has generally meant that water resource management strategies are less well developed than for perennial river basins (e.g. Benito et al., 2009). In recent decades, the growing human population in a number of dryland regions (Reynolds et al., 2007) coupled with concerns regarding the potential impact of future climate change within these hydrologically sensitive regions (Midgley et al., 2005; Midgley and Thuiller, 2007) has increased research interest in dryland flood and recharge hydrology. Scientific and technical progress is limited, however, by the lack of continuous hydrological data, scarce number of flow events and

Published by Copernicus Publications on behalf of the European Geosciences Union. 


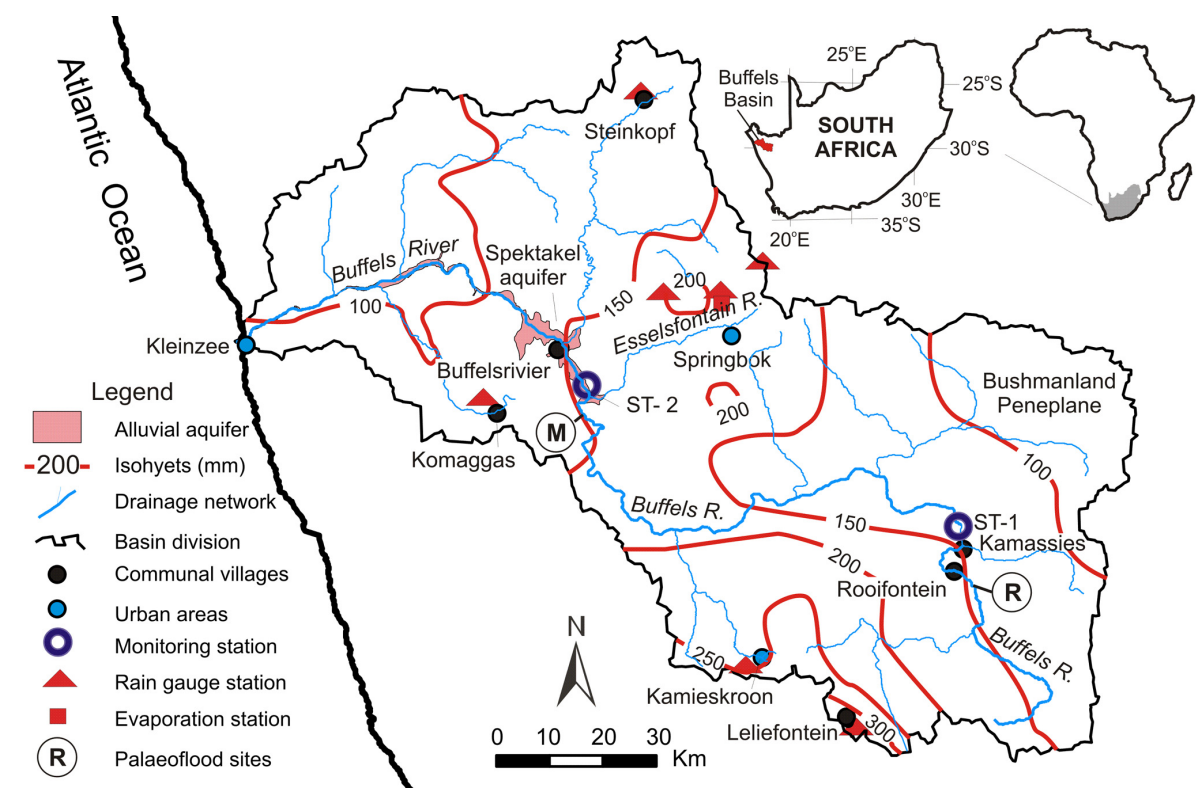

Fig. 1. The Buffels River catchment illustrating the drainage network and rainfall isohyets. The location of the WADE project monitoring stations, rainfall and evaporation stations used in the rainfall-runoff model, palaeoflood study reaches and the Spektakel aquifer system are also shown. Palaeoflood sites: circle-R, Rooifontein; circle-M, Messelpad site.

logistical/monitoring problems that may occur during the occasional large floods that produce flow (Morin et al., 2009). In addition, there is a wide diversity of ephemeral river forms and processes (Tooth, 2000), encompassing a range of hydrological, ecological and geomorphic characteristics (Knigton and Nanson, 1977; Enzel and Wells, 1997; Tooth, 2000), which limit theoretical extrapolation of results obtained from well documented dryland rivers (e.g. Reid et al., 1995). As a contribution to improving information on floodrecharge hydrology in ephemeral rivers (e.g. Greenbaum et al., 2002; Morin et al., 2009), we propose a multidisciplinary methodological approach to quantify flood discharge, floodwater volume and aquifer recharge for ungauged ephemeral rivers. The methodology was applied in the Buffels River basin, the largest ephemeral river in Namaqualand (northwest South Africa), an example of a large dryland region (ca. $45000 \mathrm{~km}^{2}$ ) with virtually no ephemeral river flow monitoring stations.

The specific objectives of this study are to: (1) generate an annual flood series through rainfall-runoff modelling for the available rainfall period 1965-2006; (2) combine the modelled flood series with non-systematic flood data derived from centennial scale documentary evidence and geomorphic palaeoflood records to improve flood frequency analysis (FFA); (3) identify the magnitude and frequency of floods required to produce significant floodwater contribution to aquifer recharge; and (4) discuss the implications of the results for flood hazards and water resources in the context of future climate projections.

\section{Study area}

The Buffels River ( $\sim 250 \mathrm{~km}$ in length) is the largest ephemeral river in Namaqualand (Northern Cape Province; South Africa) and drains an area of $9249 \mathrm{~km}^{2}$ into the Atlantic Ocean (Fig. 1). The Buffels catchment bedrock is composed of impermeable metasedimentary rocks, basic granites and ultrabasic intrusive rocks, cut by basement faults (Marais et al., 2001). Average annual precipitation is $450 \mathrm{~mm}$ near the Kamiesberg headwaters (1200-1600 m in elevation), $102 \mathrm{~mm}$ at the western Bushmanland peneplane $(914 \mathrm{~m})$, $215 \mathrm{~mm}$ at the Springbok mountains $(1067 \mathrm{~m})$ and $110 \mathrm{~mm}$ at Komaggas on the coastal plain (Fig. 1). Rainfall occurs predominantly in the austral winter between May and September, and is usually associated with frontal systems that bring gentle rain and drizzle. Towards the east of Namaqualand and the Buffels River catchment there is a transition to a predominantly summer rainfall regime which is associated with thunderstorms. As a result of this pattern, the majority of floods occur during the winter months although occasional summer rainfall may also cause flash floods. According to an oral history survey carried out in the villages of Rooifontein and Buffelsrivier (Rohde et al., 2005), the Buffels River has flooded 35 times in the last $115 \mathrm{yr}: 12 \%$ of floods occurred in early winter (April and May); 70\% during the mid-winter months (June and July), 6\% in August and 12\% during summer.

The alluvial valley fill of the Buffels River is discontinuous and basement rock outcrops form natural barriers to groundwater flow. Alluvial aquifers are therefore small and 
disconnected. These rock outcrops create a series of narrow gorge reaches where suitable sites for palaeoflood hydrology were identified (Fig. 1). In the alluvial valley, the perennial riparian vegetation is dominated by the trees Acacia karroo and Tamarix useneoides and the shrubs, Salsola aphylla and Suaeda fruticosa. Repeated photographs in the lower reaches of the Buffels River system showed little change in the cover of riparian species since 1930s (Hoffman and Rohde, 2011). The largest alluvial aquifers are located in the lower Buffels River: the Kleinzee and Spektakel aquifers (Fig. 1); the latter the focus of this study. The Spektakel aquifer is situated next to the communal village of Buffelsrivier and downstream from the Messelpad palaeoflood site. It is a $14.6 \mathrm{~km}$ long and $680 \mathrm{~m}$ wide sand-filled basin carved from granite, with alluvial sand thickness varying between $17 \mathrm{~m}$, in the southern upstream side, to nearly zero (exposed bedrock) in the northern side near the confluence with the Schaap River (Marais, 1981; Fig. 2). The average total porosity of the alluvial aquifer is $30 \%$ and the average effective porosity, or specific yield, is estimated at $20 \%$ based on laboratory and insitu field measurements (Marais, 1981). The total water bearing capacity is estimated at 20.85 million $\mathrm{m}^{3}$ with a specific yield (drainable porosity) of 13.6 million $\mathrm{m}^{3}$. Considering evaporation and other sources of natural outgoing discharge (mostly negligible), the total volume available for water abstraction is 11.33 million $\mathrm{m}^{3}$ when fully replenished (Marais, 1981; Marais et al., 2001). Water table monitoring over $27 \mathrm{yr}$ fluctuated under natural conditions between 3 and $5 \mathrm{~m}$ below the river bed level (data from O'okiep Copper Company in Marais, 1981). These observations indicate that during the period 1962 to 1981 (18 yr) full recharge only occurred twice, namely in 1962 and 1967. After full recharge in 1967, a sequence of $6 \mathrm{yr}(1968-1973)$ with abstractions at a rate between 2.2 and 2.4 million $\mathrm{m}^{3} \mathrm{yr}^{-1}$ led to nearly depleted aquifer conditions (Marais, 1981). Sustainable long-term abstraction is estimated at $0.7-0.87$ million $\mathrm{m}^{3} \mathrm{yr}^{-1}$ (Marais, 1981; Benito et al., 2009).

\section{Methodology}

The methodology applied was based on multi-source flood data including: (a) a two year continuous monitoring programme (2005-2008), (b) hydrological rainfall-runoff modelling (1965 to 2006), (c) instrumental rainfall records (1870 to 2006), (d) documentary records since AD 1810, and (e) sedimentological records for the last $700 \mathrm{yr}$ (Benito et al., 2011). The nested chronological approach provided by these overlapping periods enabled cross-checking and, in the case of the hydrological modelling, calibration allowing improved interpretation of the data.

Two hydrological monitoring stations were installed in 2005 near the communal villages of Kamassies and Buffelsrivier (Fig. 1), located in the upper and lower catchments, respectively. The monitoring system included: multilevel,

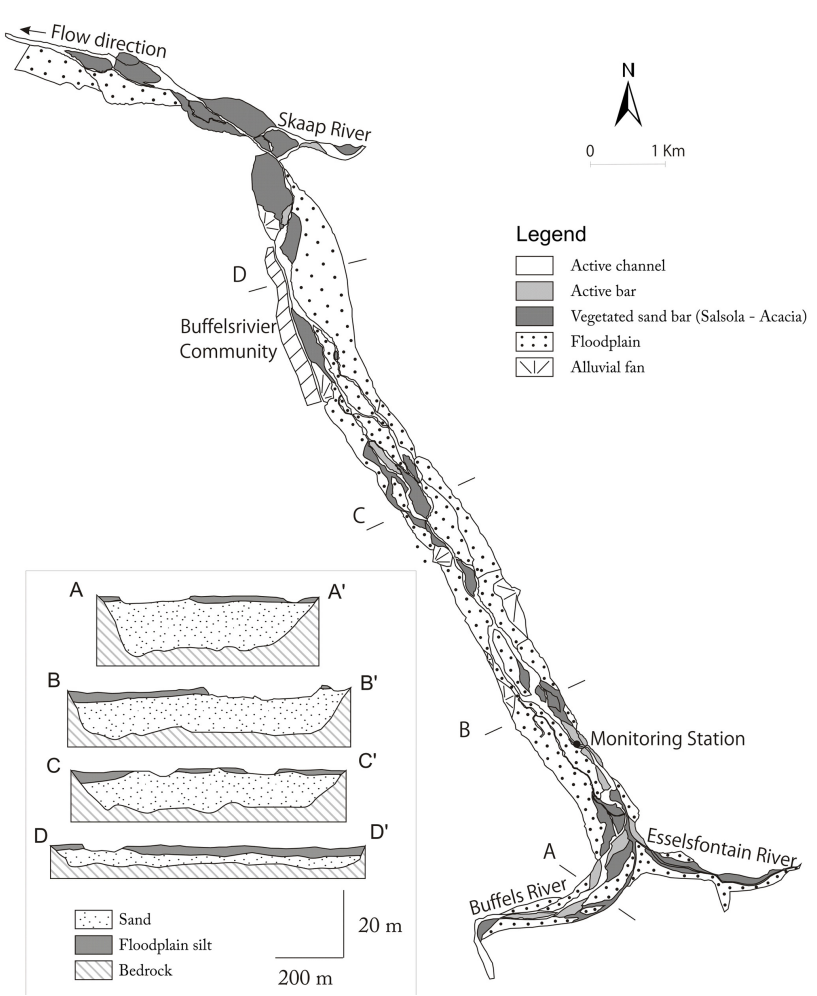

Fig. 2. Geomorphogical map showing the main fluvial units along the Spektakel aquifer and the location of the WADE project monitoring station. The aquifer cross-sections at locations A to D were adapted from Marais (1981).

Flexible Time Domain Reflectometry probes (FTDR) that were designed to measure the temporal variation of water content in the vadose zone during recharging floods; and water level devices to record flood stage and groundwater variations (Dahan et al., 2003, 2008; Rimon et al., 2007). Flood hydrographs, infiltration rates and groundwater table changes were monitored continuously between September 2005 and December 2008.

The TETIS distributed rainfall runoff model (Francés et al., 2007) was used to provide a simulated runoff series for the period 1965-2006. The model is based on the balance of water storage components in an extended soil column and runoff propagation was carried out using the kinematic wave approach. Several maps were used to feed the model with the required geomorphic characteristics of the basin: information such as slope, flow directions and flow paths (cell connection) were obtained from a digital elevation model; hydraulic conductivity of saturated rock $\left(K_{\mathrm{p}}\right)$ was derived from the regional geological map; and the SOTER-GIS for South Africa (Batjes, 2004) was used to obtain the water content capacity $\left(H_{\mathrm{u}}\right)$ and hydraulic conductivity of saturated soil $\left(K_{\mathrm{s}}\right)$. The Soil and Terrain (SOTER) report for South Africa contains soil descriptions and texture data from which hydraulic conductivity was quantified. The data from the 
SOTER-GIS map was supported with an additional 47 representative field soil descriptions in which soil horizon samples were taken for texture and chemical analysis (organic matter content, $\mathrm{pH}$, Eh, and cation exchange capacity). Soils with lower conductivity and higher soil storage capacity are located within the central and northern parts of the Buffels River basin (Fig. 3). The highest soil hydraulic conductivity values vary between 4.6 and $13.3 \mathrm{~cm} \mathrm{~h}^{-1}$, corresponding to sandy soils in the northeast and central region of the catchment. A vegetation cover index map based on data from land use, soil and geologic mapping was also used (Fig. 3).

Rainfall series from seven rainfall gauge stations, which covered most of the Buffels River catchment (Fig. 1), were used in the modelling. Calibration was performed on: (a) correction factors for runoff production and propagation; (b) the initial conditions of storage stage; and (c) the correlation coefficient between precipitation and elevation for the spatial interpolation of rainfall distribution. For model calibration, a data sequence of daily discharges from 27 September 2005 to 28 July 2006 was used, whilst the validation was performed using the period 29 July to 29 September 2006. In both of these periods at least one flood event at Buffelsrivier and Kamassies was recorded. Once the model was calibrated and validated, daily stream flow data were obtained for the period 1965 to 2006, the timespan for which the most complete rainfall record is available. For practical purposes modelling output results were focused on the palaeoflood study reaches to enable comparison between the systematic and non-systematic discharge records.

Flood frequency analysis (FFA) was carried out on the combined modelled annual flood series for the period 1965 to 2006 (considered as systematic data) and the non-systematic record compiled from historical documents (Kelso and Vogel, 2007) and palaeoflood hydrology. The methodology and results of these palaeoflood records are discussed in Benito et al. (2011). A set of probability distribution functions was fitted to the reconstructed flood data series and the parameters of these distribution functions were estimated by the maximum likelihood method (Stedinger and Cohn, 1986). The two-component extreme value (TCEV) distribution was finally selected on the basis of best statistical estimators of adjustment. Associated infiltration/recharge volumes for various return period floods at the Spektakel alluvial aquifer were estimated for different probabilistic hydrographs. A probabilistic hydrograph is defined as one that preserves a peak discharge exceedance probability and dependence between volume and peak for a fixed duration (England, 2003). Hydrograph durations were fixed to the most common observed occurrences, namely 6 days for discharges less than $50 \mathrm{~m}^{3} \mathrm{~s}^{-1}$ and 12 days for flood discharges over $50 \mathrm{~m}^{3} \mathrm{~s}^{-1}$. The hydrograph volume was estimated on the basis of two dimensionless hydrographs by visually selecting a representative shape of the modelled hydrographs from a sample of twenty small floods $\left(Q<50 \mathrm{~m}^{3} \mathrm{~s}^{-1}\right)$ and two large floods $\left(Q>50 \mathrm{~m}^{3} \mathrm{~s}^{-1}\right)$.
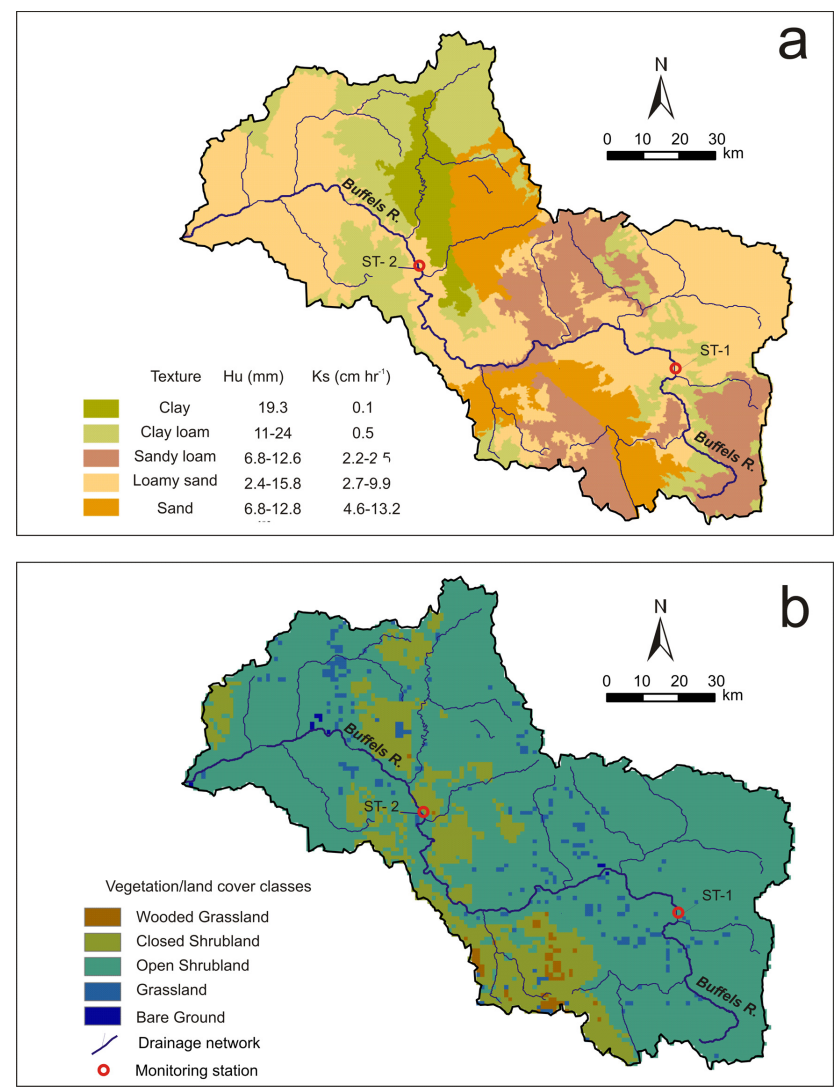

Fig. 3. (a) Soil texture and (b) vegetation cover index maps of the Buffels River catchment.

For the quantification of aquifer recharge, surface alluvial units exposed to floodwater infiltration were mapped (Fig. 2) based on aerial photographs of the study reach. The main geomorphological units include channel bed, sand bars (vegetated and non-vegetated), the floodplain and first alluvial terrace. The average width for each of these geomorphological units was determined by applying a GIS algorithm, developed by Morin et al. (2009), to the aerial photographs. A characteristic cross-section with the support of field survey elevations of each geomorphic unit was then constructed. A rating curve for the synthetic cross-section was estimated using the Manning's equation (uniform flow conditions) to determine the minimum flood discharges required to inundate these geomorphological units. Full aquifer recharge was estimated assuming two pre-flood conditions: namely for a water table set at $3 \mathrm{~m}$ below the channel bed (corresponding to a maximum recharge volume of 9 million $\mathrm{m}^{3}$ ); and empty aquifer conditions, quantified by Marais (1981) as a recharge volume of 13.6 million $\mathrm{m}^{3}$. 


\section{Results}

\subsection{Reconstruction of annual hydrologic records}

\subsubsection{Stream flow monitoring record}

The 2005-2006 flows recorded at Buffelsrivier lasted for forty days (Fig. 4a), with flow hydrographs showing peaks which fit the rainfall associated with the passage of winter fronts. Most of the Buffels River flows were recorded at both the upper and lower monitoring stations. Winter flows were recorded first at Buffelsrivier in the lower basin reaching Kamassies in the upper catchment after a delay that typically ranged between 6 and $12 \mathrm{~h}$. This reflects the passing of west to east frontal systems across the basin (Fig. 1). Summer rains produced short-lived floods $(<1$ day of duration) with peak discharges half the size of the winter flows. The largest flow peak was recorded in May 2006, reaching a discharge of $20 \mathrm{~m}^{3} \mathrm{~s}^{-1}$ at Buffelsrivier (Fig. 4a) and $8 \mathrm{~m}^{3} \mathrm{~s}^{-1}$ at Kamassies.

\subsubsection{Rainfall-runoff modelling}

The widespread winter rainfall conditions in the Buffels catchment provide optimal data for rainfall-runoff modelling to generate discharge data. Daily discharge and annual flood series (1965-2006) were estimated (Fig. 4a and b) using the TETIS model based on hourly and daily rainfall provided by seven rain gauge stations distributed throughout the catchment. The model performance was satisfactory with a Nash-Sutcliffe (NS) efficiency coefficient of 0.78 for the calibration results ( $>0.6$ considered as reasonably good). The simulated versus recorded hydrograph volumes showed errors of $7 \%$ and $24 \%$ for the calibration and validation hydrographs respectively (Fig. 4a). The largest modelled discharge was obtained for 29 July 2002. At Rooifontein this flood event provided a simulated peak of $63 \mathrm{~m}^{3} \mathrm{~s}^{-1}$, with river flow spanning 11 days resulting in a hydrograph volume of 7.7 million $\mathrm{m}^{3}$. Downstream at Messelpad the simulated flood peak for the event was $106 \mathrm{~m}^{3} \mathrm{~s}^{-1}$ again with a flow duration of 11 days and a corresponding flood volume of 21 million $\mathrm{m}^{3}$ (Fig. 4b). During the simulated period, only three floods were over $50 \mathrm{~m}^{3} \mathrm{~s}^{-1}$ at Messelpad, all three events occurred between 2001-2002. Another two floods were estimated at $40 \mathrm{~m}^{3} \mathrm{~s}^{-1}$ during the winters of 1996 and 1997, corresponding with above average annual rainfall in Springbok. During the period 1965-1996, only two isolated floods (1967 and 1974) surpassed $20 \mathrm{~m}^{3} \mathrm{~s}^{-1}$ at Messelpad, a similar magnitude to the event recorded at the monitoring station in 2006 (Fig. 4a).

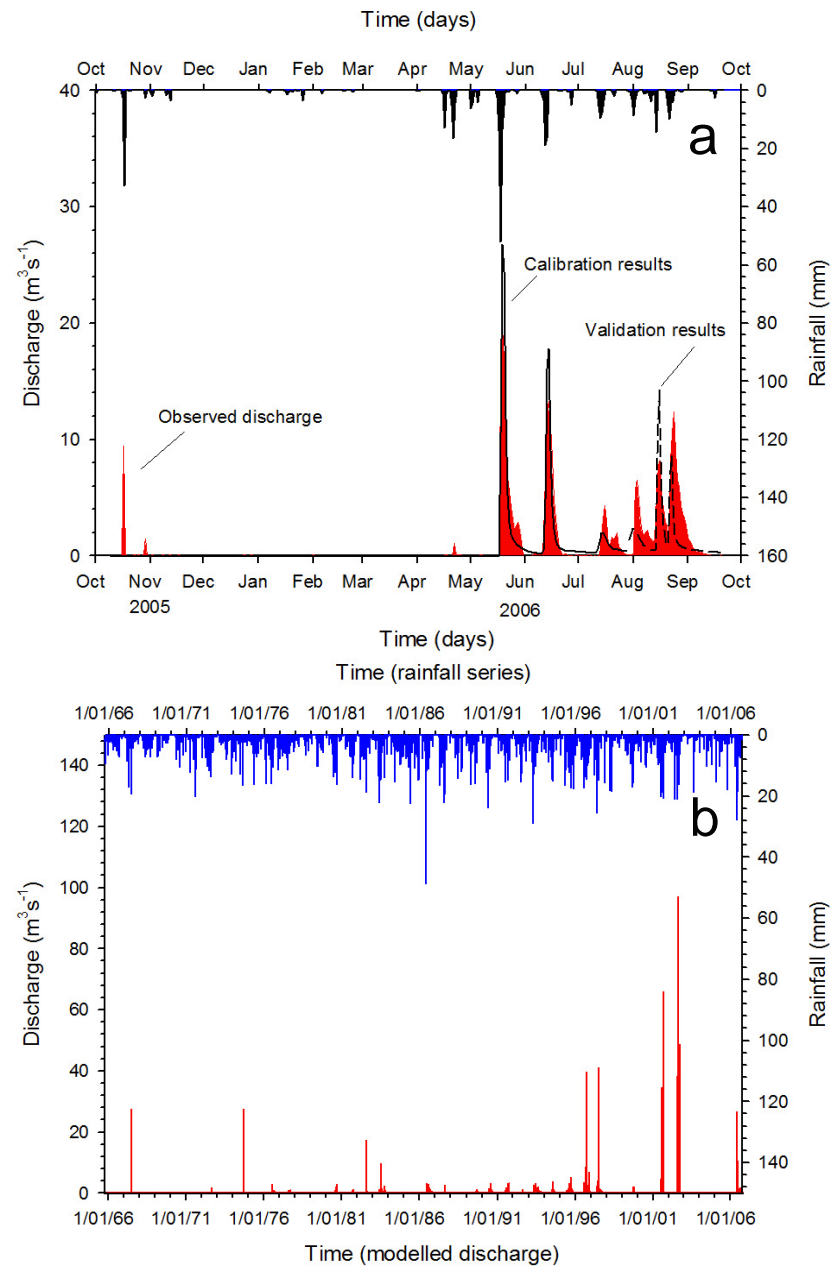

Fig. 4. (a) Surface water discharge (in red) recorded at the Buffelsrivier WADE monitoring station (lower catchment) and results of the calibration (black solid line) and validation (black dashed line) for the TETIS distributed rainfall-runoff model based on seven rainfall gauges. (b) Daily rainfall and daily peak discharge modelled for the period 1968-2005 at Messelpad (lower catchment).

\subsection{Reconstruction of non-systematic flood data}

\subsubsection{Documentary and historical flood records}

Climatic and hydrological documentary records (starting in 1810) for Namaqualand and the Buffels river catchment were obtained from written descriptions at missionary stations (Kelso and Vogel, 2007). The oldest written reference to rainfall describes 1818 as a wet year, with other good winter rains occurring in AD 1822-1823, 1831, 1859, 1872, $1878,1888,1899$ and 1900. Documentary records indicate AD 1888 as a year with exceptional winter rainfalls during which ephemeral rivers flowed for several months (Kelso and Vogel, 2007). This is corroborated by the overlapping rainfall instrumental data recorded at Springbok (1870 to 2006; Fig. 5), where 1888 is the third largest winter precipitation 


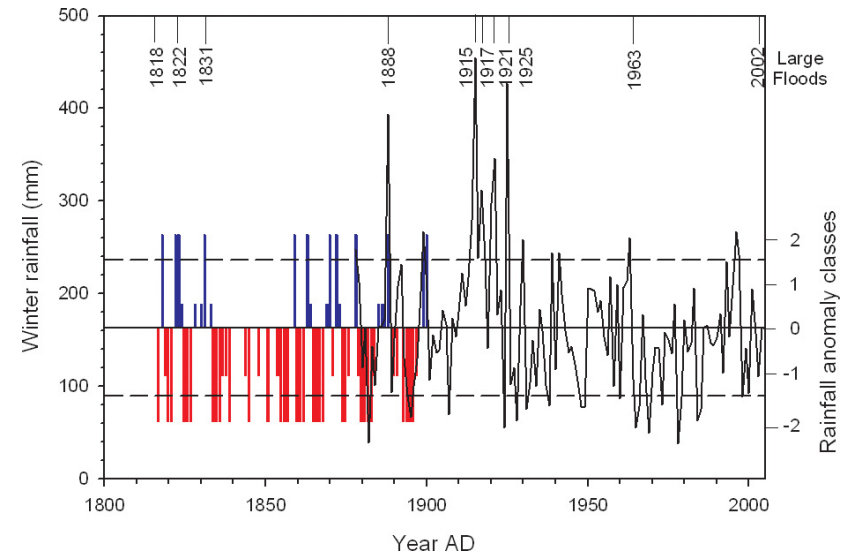

Fig. 5. Rainfall record of the Springbok rain station (1878-2006, black line) and rainfall anomaly classes (red bars: drought/dry years; blue bars: wet/normal years) from the documentary records of Kelso and Vogel (2007). Rainfall anomaly class values are only for illustrative purposes: -2 drought year; -1 dry year; +0.5 normal year; 2 wet year. Years with insufficient evidence are not plotted. Documented flood years are indicated in the upper $\mathrm{x}$-axis.

on record (394 mm: $+94 \%$ of annual rainfall). During the 20th Century, the rank of winter precipitation at Springbok is headed by $1915(454 \mathrm{~mm})$ followed by $1925(427 \mathrm{~mm})$, $1921(346 \mathrm{~mm}), 1917(311 \mathrm{~mm}), 1920(297 \mathrm{~mm})$ and 1914 $(279 \mathrm{~mm})$. These fall in the wettest decade (1915-1925) of winter rainfall in the record. Since then, there has been a shift towards decreasing the mean decadal precipitation (Fig. 5).

\subsubsection{Sedimentary palaeoflood records}

The detailed analysis of the sedimentary flood record and a discussion of dating errors, both of which are beyond the scope of this paper, are provided in Benito et al. (2011). Here we present the downstream channel profiles and selected modelled floodwater elevations at the Rooifontein (Fig. 6) and Messelpad (Fig. 7) study reaches, as well as the synthesised flood records extending back to AD 1400 at Rooifontein and AD 1500 at Messelpad (Fig. 8). Modelled water surface profiles for floods of 100 and $310 \mathrm{~m}^{3} \mathrm{~s}^{-1}$, routed through the Rooifontein reach, are presented in Fig. 6. The figure illustrates the relationship between the floodwater elevations and the sites of flood sediment deposition, with a simplified indication of sediment ages also presented. The discharge estimation may be compromised at the Rooifontein reach due to scour and fill within the channel bed (see the photograph in Fig. 6 which shows sediment infilling the channel). By contrast the Messelpad reach, where there is exposed bedrock and limited in-channel sediment deposition, is optimal for palaeodischarge reconstruction (Fig. 7). The downstream channel profile here is presented with calculated water surface profiles of 460 and $510 \mathrm{~m}^{3} \mathrm{~s}^{-1}$, which are the discharges associated with the highest elevation flood deposits at the site (Fig. 7).
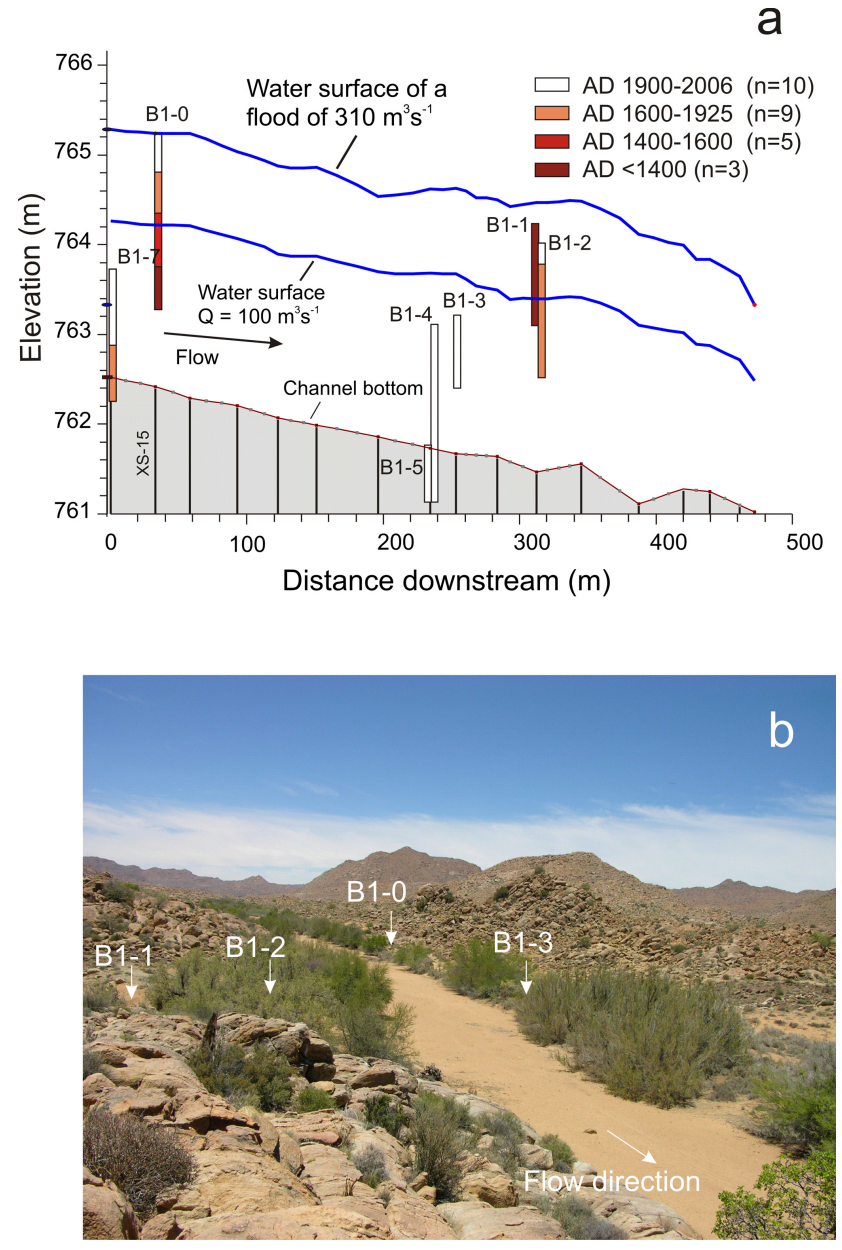

Fig. 6. Rooifontein study reach: (a) longitudinal profile of the stream channel bed and water surface profiles obtained from HECRAS modelling for the highest palaeoflood deposits $\left(310 \mathrm{~m}^{3} \mathrm{~s}^{-1}\right)$ and for a reference discharge of $100 \mathrm{~m}^{3} \mathrm{~s}^{-1}$. Stratigraphic profiles are represented as vertical bars, with colours sketching flood sediments of different age. In the legend, $\mathrm{n}$ is the number of floods recorded in a given period. (b) General upstream view of the Rooifontein reach and location of four stratigraphic profiles B1-0, B1-1, B1-2 and B1-3.

\subsection{Flood Frequency Analysis (FFA) combining modelled discharges and non-systematic records}

The combined systematic and palaeoflood data is synthesised in Fig. 8a1 and b1, where best-estimate ages are provided for the individual palaeofloods (see Benito et al., 2011). The palaeoflood data represents floods exceeding a given discharge threshold $\left(Q_{\mathrm{h}}\right)$ in a period of known duration, the discharge threshold defined by the elevations of the flood depositional zones, such as flood benches. The stratigraphic record is assumed to be complete for each flood exceeding the threshold of discharge at the palaeoflood site. As such, palaeoflood information can be treated as censored data, which can be handled efficiently by appropriate statistical 

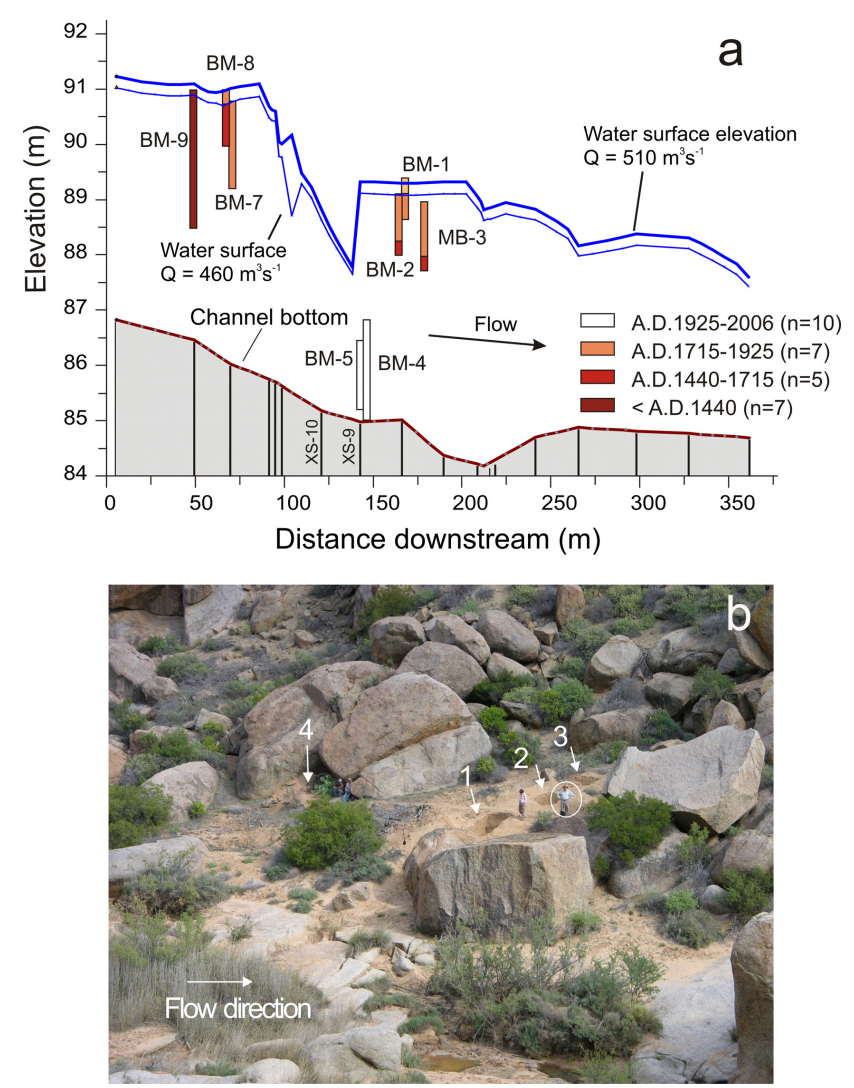

Fig. 7. Messelpad reach: (a) longitudinal profile of the stream channel bed and water surface profiles obtained from HEC-RAS modelling (Hydrologic Engineering Center, 1995) for the highest palaeoflood deposits $\left(510 \mathrm{~m}^{3} \mathrm{~s}^{-1}\right)$ and for a reference discharge of $460 \mathrm{~m}^{3} \mathrm{~s}^{-1}$. Stratigraphic profiles are represented as vertical bars, with colours sketching sections of flood sediments of different age. (b) General view of the upper section of the Messelpad study reach, and location of three profiles: BM-7 (1), BM-8 (2), and BM-9 (4).

methods (Stedinger and Cohn, 1986; Francés et al., 1994). Frequency analysis of a 500-yr flood record introduces the question of flood stationarity, since cyclic and systematic climatic and land-use conditions may affect the assumption of statistical parametric models on which the random variable (flood discharge) is independent and identically distributed (see discussion in Redmond et al., 2002; Francés, 2004). Lang et al. (1999) proposed a stationarity test for nonsystematic censored samples that assumes the peak-overthreshold flood series can be described by a homogenous Poisson process. Lang's stationarity test was passed for the combined flood record at Rooifontein (covering the period 1317-2006) with a lower threshold discharge of $94 \mathrm{~m}^{3} \mathrm{~s}^{-1}$; and for Messelpad flood record (period 1526-2006) for a threshold discharge of $460 \mathrm{~m}^{3} \mathrm{~s}^{-1}$. This indicates, therefore, that the flood series for the Buffels River are suitable for flood frequency analysis.
The associated FFA curves are shown in Fig. 8a2 and b2 for the Rooifontein and Messelpad reaches respectively, with a two-component extreme value (TCEV) distribution fitted to: firstly the annual series of modelled discharges only; then the combined modelled and censored palaeoflood data where the grey shaded threshold values are used in the FFA. For the Rooifontein reach in the upper basin, 12 palaeoflood discharges were included, all as lower bound type, with the largest palaeoflood discharge of $255 \mathrm{~m}^{3} \mathrm{~s}^{-1}$, significantly greater than the largest discharge $\left(63 \mathrm{~m}^{3} \mathrm{~s}^{-1}\right)$ for the modelled annual series (Fig. 8a1). The incorporation of the palaeoflood data into the FFA results in higher values in the magnitude of the flood quantiles (Fig. 8a2; Table 1). In fact, discharge quantiles provided by combining palaeoflood and simulated data are approximately three times larger than ones obtained from annual simulated discharge series alone. For example, the largest palaeoflood discharge $\left(255 \mathrm{~m}^{3} \mathrm{~s}^{-1}\right)$ is associated with an average return period of $450 \mathrm{yr}$, whilst the maximum simulated discharge $\left(63 \mathrm{~m}^{3} \mathrm{~s}^{-1}\right)$ represents an average recurrence interval of $20 \mathrm{yr}$ (Fig. 8a2).

At Messelpad in the lower basin, a total of 12 palaeofloods were included in the FFA, the six palaeofloods post-dating $1750 \mathrm{AD}$ are lower bound type whilst five floods identified between 1600 and $1750 \mathrm{AD}$ are defined using a double censored interval (Fig. 8b1). During AD 1600-1800 flood sedimentation occurred exceeding a lower flood bench (threshold level $Q_{\mathrm{h} 2}$ ) but there is no stratigraphic evidence of flood deposition on the oldest flood bench, which therefore defines an upper threshold level $Q_{\mathrm{h} 1}$. At this site, the largest palaeoflood discharge was $510 \mathrm{~m}^{3} \mathrm{~s}^{-1}(\sim 1 \%$ annual probability flood) and the largest annual modelled discharge reached $106 \mathrm{~m}^{3} \mathrm{~s}^{-1}$ ( $\sim 10 \%$ annual probability). The visual fit of the palaeoflood plotting positions (Fig. 8b2) in relation to the adjusted distribution function is not as good as at Rooifontein. However, this visual discrepancy does not affect the quality of the results. Plotting positions represent an exceedence probability for a flood of known magnitude. In the case of palaeoflood data, the exact flood discharge is unknown, so their plotting positions are drawn using minimum discharge values while the frequency function is estimated considering these palaeoflood discharges as lower bound data. As a result, the performance of the statistical adjustment based on a visual fit as used in conventional hydrology is not applicable in this case. The FFA from both sites combining the annual modelled flood series and palaeoflood discharges illustrates that floods of a given magnitude are more frequent than estimations based on systematic records alone (Table 1). The implications of the FFA results are discussed in relation to aquifer recharge in the next section. 

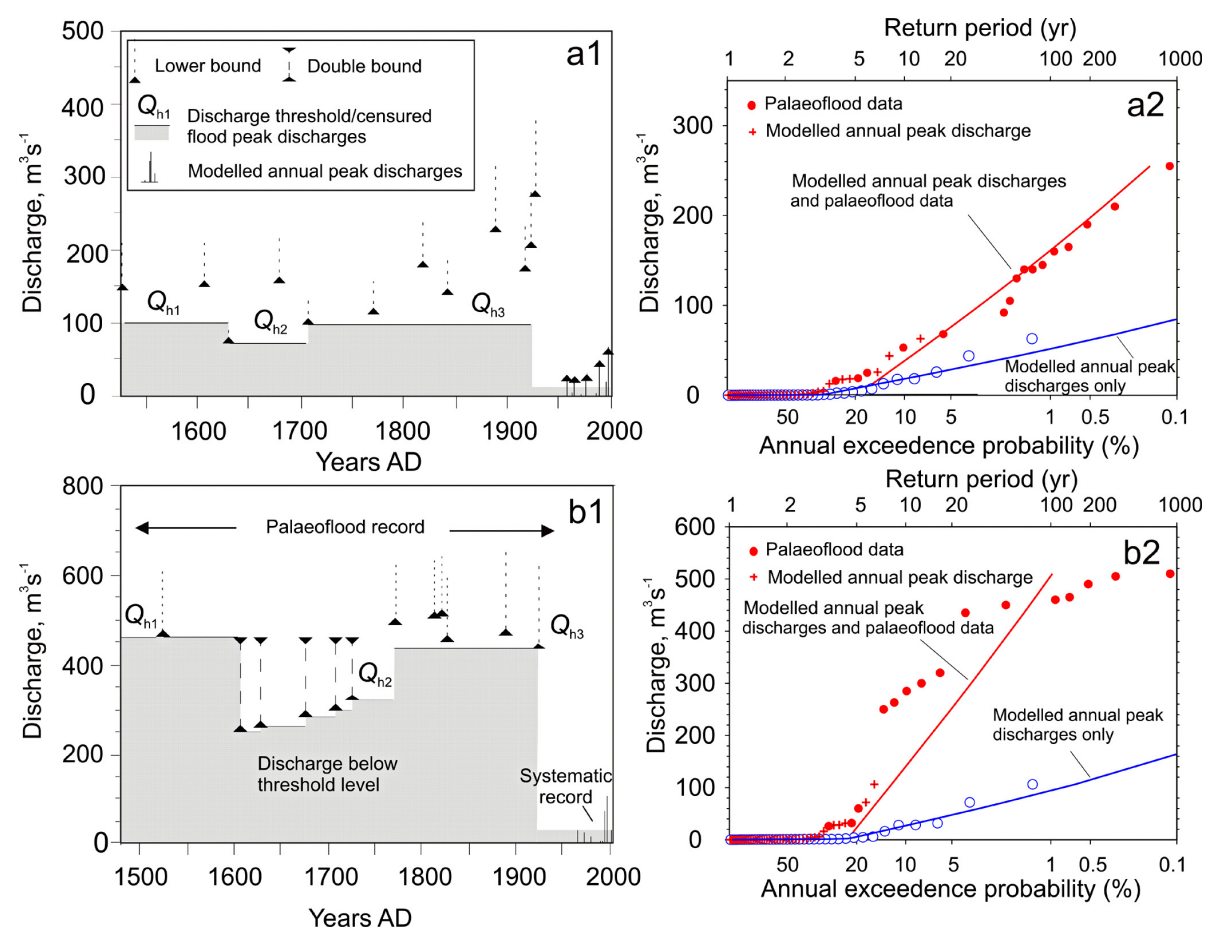

Fig. 8. Palaeoflood and modelled discharges at Rooifontein (a1) and Messelpad (b1). The horizontal shaded areas represent the discharge threshold values $\left(Q_{\mathrm{h}}\right)$ used in the flood frequency analysis. Two component extreme value distributions fitted to annual series of modelled peak discharges and palaeoflood information (censored data) for Rooifontein (a2) and Messelpad (b2).

Table 1. Flood quantiles for different return periods for the Rooifontein and Messelpad sites obtained using a two-component extreme value (TCEV) distribution fitted to firstly the annual series of modelled discharges only, then the combined modelled and censored palaeoflood data.

\begin{tabular}{|c|c|c|c|c|c|}
\hline \multirow{3}{*}{$\begin{array}{r}\text { Annual } \\
\text { Exceedence } \\
\text { Probability (\%) }\end{array}$} & \multirow{3}{*}{$\begin{array}{l}\text { Average } \\
\text { Recurrence } \\
\text { Interval, yr }\end{array}$} & \multicolumn{4}{|c|}{ Peak discharge $\mathrm{m}^{3} \mathrm{~s}^{-1}$} \\
\hline & & \multicolumn{2}{|c|}{ Rooifontein } & \multicolumn{2}{|c|}{ Messelpad } \\
\hline & & $\begin{array}{r}\text { Modelled } \\
\text { series }\end{array}$ & $\begin{array}{l}\text { Palaeoflood } \\
\& \text { Modelled }\end{array}$ & $\begin{array}{r}\text { Modelled } \\
\text { series }\end{array}$ & $\begin{array}{l}\text { Palaeoflood } \\
\text { \& Modelled }\end{array}$ \\
\hline 20 & 5 & 8 & 8 & 6 & 23 \\
\hline 10 & 10 & 18 & 56 & 27 & 140 \\
\hline 4 & 25 & 32 & 117 & 54 & 287 \\
\hline 2 & 50 & 42 & 162 & 74 & 397 \\
\hline 1 & 100 & 52 & 207 & 94 & 505 \\
\hline 0.2 & 500 & 74 & 309 & 139 & 752 \\
\hline
\end{tabular}

\section{Long-term floodwater resources and their contribution to aquifer recharge}

Floods are usually viewed as a natural hazard due to their potential damage to society and ecosystems. In arid environments, however, floods are an important source of water resulting in long-lasting water pools and the recharge of alluvial aquifers (Matlock and Davis, 1972; Enzel and Wells, 1997, Morin et al., 2009). Both natural ecosystems and human societies depend on this scarce water source to maintain life in arid lands (e.g., Seely et al., 1981). In most ephemeral rivers worldwide, there is limited data on which to base an evaluation of the long-term frequency of recharging floods, data that is of crucial importance for integrated water resource management (Benito et al., 2009). The proposed multi-disciplinary methodology has provided a means of quantifying long-term flood records for ungauged ephemeral rivers and examining the relationships between flood magnitude and frequency and aquifer recharge. 
Floodwater contribution to alluvial aquifer recharge in the lower Buffels River was estimated using a set of scaled probabilistic hydrographs with peak flows matching those of the FFA (Sect. 4.3). At the Buffelsrivier reach (Fig. 9), flood volumes estimated for the probabilistic scaled hydrographs range between 4 million $\mathrm{m}^{3}$ (for a flood with average recurrence interval of $5 \mathrm{yr}$ ) to 144 million $\mathrm{m}^{3}$ (average recurrence interval of $500 \mathrm{yr}$; Table 2). A separate issue is the infiltration potential, which is the hydrograph volume able to infiltrate assuming an unlimited aquifer capacity (Shentsis and Rosenthal, 2003). The infiltration potential is mainly dependent on infiltration rate, inundation surface and flow duration. The infiltration rate of the channel bed at Buffelsrivier occurs at an average flux of $6 \mathrm{~cm} \mathrm{~h}^{-1}$, according to the monitoring station records, whilst an average water flux of $1 \mathrm{~cm} \mathrm{~h}^{-1}$ was estimated for the floodplain sediments which have a similar grain-size distribution to a monitored reach of the Kuiseb River in Namibia (Dahan et al., 2008). The potential infiltration volumes of the Spektakel aquifer were estimated as 4 million $\mathrm{m}^{3}$ for a flood with 5 years of average recurrence interval, and up to 23 million $\mathrm{m}^{3}$ for a flood with $500 \mathrm{yr}$ of average recurrence interval (Table 2). Morin et al. (2009) demonstrated in the Kuiseb River that floodwater infiltration into the alluvial aquifer is mainly sensitive to flood duration and not so much to flood peak discharge, but this is also dependent on river length and aquifer extension. In the Buffels River, however, flood magnitude controls the extent of inundation as for certain flood stages inundation area may cover sand bars and a wider area of the floodplain, increasing the infiltration volume per unit time. The daily infiltration volumes for floods $\left(Q<50 \mathrm{~m}^{3} \mathrm{~s}^{-1}\right)$ covering only the channel bed is 2.7 million $\mathrm{m}^{3}$, whilst subsequent inundation of sand bars $\left(Q>50 \mathrm{~m}^{3} \mathrm{~s}^{-1}\right)$ and floodplain areas $\left(Q>370 \mathrm{~m}^{3} \mathrm{~s}^{-1}\right)$ increases the daily infiltration volume to 3.8 and 6 million $\mathrm{m}^{3}$, respectively. In a single flood, the mean peak annual discharge from the TCEV distribution fitted to the systematic and palaeoflood data, obtained from the expression developed by Beran et al. (1986), was $0.58 \mathrm{~m}^{3} \mathrm{~s}^{-1}$ with an estimated recharge volume of $105000 \mathrm{~m}^{3}$. Despite this high floodwater infiltration potential, actual recharge is limited by the water storage potential to full saturation, which depends on water table depth prior to flooding (Morin et al., 2009) as once the groundwater level reaches the surface, transmission losses and recharge cease. In the Spektakel aquifer the water table is relatively shallow $(3-5 \mathrm{~m}$ below channel bed) even during drought periods due to lateral subsurface flow from the crystalline basement bedrock (Fersch, 2007). In other arid basins where groundwater is deeper (e.g. Mohave River in southern California; Enzel and Wells, 1997) recharge is highly dependent on flood magnitude. An estimation of the probabilistic flood producing effective recharge was undertaken based on two aquifer conditions: a nearly empty aquifer (recharge capacity of 13.6 million $\mathrm{m}^{3}$ ), and with a water table elevation of $3 \mathrm{~m}$ ( 9 million $\mathrm{m}^{3}$ capacity). The results show that effective recharge is related to fre-

\section{Dimensionless hydrographs}

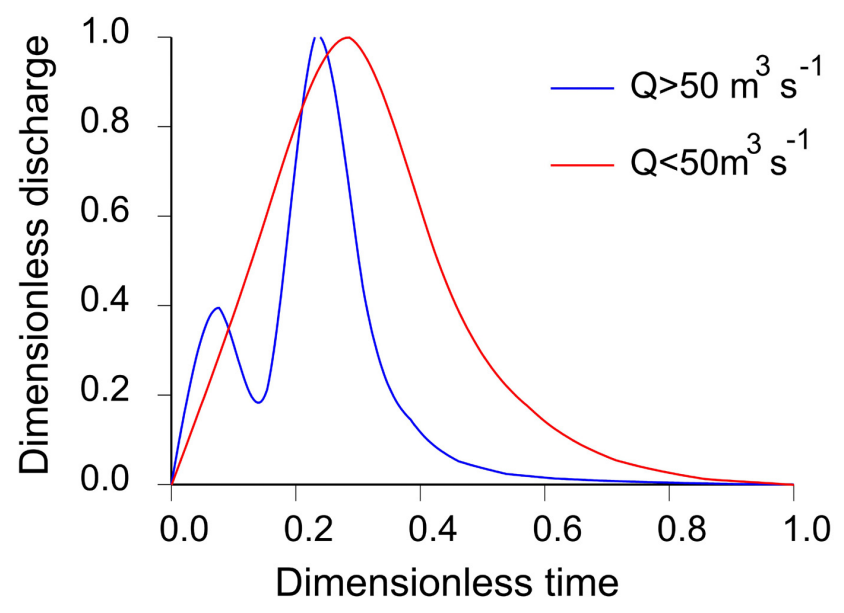

Fig. 9. The dimensionless hydrographs selected from a set of modelled hydrographs for small $\left(Q<50 \mathrm{~m}^{3} \mathrm{~s}^{-1}\right)$ and large floods $\left(Q>50 \mathrm{~m}^{3} \mathrm{~s}^{-1}\right)$.

quent floods (10-20\% annual probability floods), whereas for larger flood magnitude/frequency the water table reaches the surface and recharge ceases. This has implications for water resource management under future climate scenarios in southern African ephemeral rivers flowing through landscapes dominated by basement granitic and metamorphic lithologies. Despite the long-term flood record indicating a reduction in flood magnitude during the last century, a result consistent with future reductions in runoff modelled for global warming scenarios (Milly et al., 2005), there is unlikely to be such a negative impact on the available volume of alluvial aquifer water resources. There could potentially, however, be issues affecting water quality as evaporation of the shallow groundwater in-between flows is increasing salinity, an issue noted in the communal villages of Buffelsrivier and Rooifontein. This will be especially so if rainfall and flood frequencies decrease under future climate scenarios. Historical observations indicate saturation of the Spektakel alluvial aquifer associated with rainfalls of $>75 \mathrm{~mm}$ over a period of at least two weeks, causing runoff within the slopes and flow of the main stream and its tributaries (Marais, 1981). One possible management solution that could be investigated is the possibility to increase the effective infiltration volume by pumping the alluvial aquifer water, thus lowering the water level along the aquifer length to increase floodwater recharge potential. This could also improve water quality due to the low salt content of floodwaters in relation to higher salinity input from lateral flow.

\section{Conclusions}

The scarcity of flow gauge records in many dryland, ephemeral rivers is a major limitation in the assessment of flood risk and water resources. This is of critical importance 
Table 2. Peak flood discharges estimated from FFA based on modelled and palaeoflood data at Messelpad ( $\sim 5 \mathrm{~km}$ upstream of Spektakel aquifer reach) and characteristics of the probabilistic hydrographs based on dimensionless hydrographs and a fixed duration of 6 days for small floods $\left(Q<50 \mathrm{~m}^{3} \mathrm{~s}^{-1}\right)$ and 12 days for large floods $\left(Q>50 \mathrm{~m}^{3} \mathrm{~s}^{-1}\right)$. Potential infiltration considers all the possible infiltration for the given probabilistic hydrograph assuming a limitless capacity of the aquifer. Infiltration was also estimated for two initial aquifer conditions assuming $\mathrm{a}^{\mathrm{a}}$ water table (WT) at $3 \mathrm{~m}$ below the surface and ${ }^{\mathrm{b}}$ an empty aquifer at the time of flooding.

\begin{tabular}{|c|c|c|c|c|c|c|c|}
\hline $\begin{array}{r}\text { Annual } \\
\text { Exceedence } \\
\text { Probability (\%) }\end{array}$ & $\begin{array}{r}\text { Average } \\
\text { Recurrence } \\
\text { Interval, years }\end{array}$ & $\begin{array}{r}\text { Peak } \\
\text { discharge, } \\
\mathrm{m}^{3} \mathrm{~s}^{-1}\end{array}$ & $\begin{array}{r}\text { Duration, } \\
\text { Days }\end{array}$ & $\begin{array}{r}\text { Hydrograph } \\
\text { volume, } \\
\times 10^{6} \mathrm{~m}^{3}\end{array}$ & $\begin{array}{r}\text { Potential } \\
\text { Infiltration, } \\
\times 10^{6} \mathrm{~m}^{3}\end{array}$ & $\begin{array}{r}\text { Infiltration to } \\
\text { saturation } \\
\text { WT:3 } \mathrm{m}, \times 10^{6} \mathrm{~m}^{3}\end{array}$ & $\begin{array}{l}\text { Infiltration to } \\
\text { saturation } \\
\quad \times 10^{6} \mathrm{~m}^{3}\end{array}$ \\
\hline 20 & 5 & 23 & 6 & 4.2 & 4.2 & 4.2 & 4.20 \\
\hline 10 & 10 & 140 & 12 & 27.9 & 11.8 & 9.0 & 11.83 \\
\hline 4 & 25 & 287 & 12 & 53.9 & 17.9 & 9.0 & 13.60 \\
\hline 2 & 50 & 397 & 12 & 76.2 & 18.0 & 9.0 & 13.60 \\
\hline 1 & 100 & 505 & 12 & 97.0 & 21.3 & 9.0 & 13.60 \\
\hline 0.2 & 500 & 752 & 12 & 144.4 & 22.9 & 9.0 & 13.60 \\
\hline
\end{tabular}

given current interest in assessing the response of such rivers to future global change, especially when future climate scenarios predict reduced runoff, as is the case for dryland regions of southern Africa (Milly et al., 2005). Here, we have proposed a multi-source inter-disciplinary approach applied to improve our understanding of flood magnitude/frequency and aquifer recharge in ephemeral river hydrology. Daily discharge and annual flood series (1965-2006) were estimated using the TETIS distributed rainfall-runoff hydrological model (Francés et al., 2007) based on hourly and daily rainfall provided by seven rain gauge stations distributed throughout the catchment. The model was calibrated and validated during a two year monitoring programme (20052006) at two stream flow stations, one in the upper catchment and one in the lower basin. Significant flood-producing rainfall events were linked to westerly winter frontal systems passing over the catchment for several days, with floods recorded first in the lower basin reflecting the west to east passage of the rainfall. In the upper catchment at Rooifontein the largest monitored flood (May 2006) reached $8 \mathrm{~m}^{3} \mathrm{~s}^{-1}$ whilst the largest modelled flood gave a simulated peak of $63 \mathrm{~m}^{3} \mathrm{~s}^{-1}$, the latter flowing for 11 days. At Messelpad in the lower catchment, the same rainfall events generated the largest monitored flood of $20 \mathrm{~m}^{3} \mathrm{~s}^{-1}$ and the largest modelled peak flow of $106 \mathrm{~m}^{3} \mathrm{~s}^{-1}$, showing a proportional hydrological response throughout the basin.

The magnitude and frequency of floods in the preinstrumental period were retrieved from a combination of documentary descriptions at missionary stations, reported by Kelso and Vogel (2007), and from sedimentary evidence (slack-water flood deposits) using the methodology of palaeoflood hydrology. The palaeoflood record, with more than 25 floods preserved over the last $700 \mathrm{yr}$ (Benito et al., 2011), was reconstructed based on the assumptions that: (1) floods recorded at multiple sites occurred on the same dates throughout the catchment; and (2) the record is censored, with event preservation dependent on flood water lev- els exceeding the threshold elevation of previous deposits at sites of deposition.

In terms of flood magnitude, large floods occurred throughout the centennial palaeoflood record. The largest palaeodischarge(s) in the upper catchment reached a minimum discharge of $310 \mathrm{~m}^{3} \mathrm{~s}^{-1}$ compared to $510 \mathrm{~m}^{3} \mathrm{~s}^{-1}$ in the lower basin. These palaeofloods were up to five times greater than the largest modelled peak discharges during the 19652006 period. FFA using the combined modelled and palaeoflood discharges, and based on maximum likelihood estimators, was successfully fitted to a two-component extreme value distribution. The fitted distribution shows an average return period of ca. 500 and $100 \mathrm{yr}$ for the largest palaeoflood discharges in the upper and lower reaches respectively, whilst the largest simulated discharges are associated with average return period of $10 \mathrm{yr}$.

The reconstructed flood data were applied to estimate aquifer recharge in the lower basin. Dimensionless hydrographs scaled to the probabilistic flood discharge showed that effective recharge is produced by relatively small floods (return periods of 5-10 yr), since floods exceeding ca. 120$140 \mathrm{~m}^{3} \mathrm{~s}^{-1}$ and 12 days duration are able to fully saturate the aquifer. As a result flood magnitude plays a limited role in controlling the infiltrated water volume within alluvial aquifers in these relatively short ephemeral rivers flowing over basement rocks. This suggests that the decreasing runoff predicted for the region under future global warming scenarios (Milly et al., 2005) will not have such a negative impact on the water resource availability from shallow alluvial aquifers, although more research is needed to predict the impact on water quality and in particular salinity.

Acknowledgements. The study was funded by the 6th framework of the European Community through the project "FloodWater recharge of alluvial Aquifers in Dryland Environments", WADE Project (contract no. GOCE-CT-2003-506680), and by the Spanish Ministry of Science and Technology (CICYT) grant GL200806474-CO2-01. Daferey Waldeck (Rooifontein), Anna Marie 
Boyce (Buffelsriver) and Penny Price (University of Cape Town) are gratefully thanked for their field assistance. Azucena Chueca kindly drafted Fig. 2 of this paper, and carried the GIS analysis. We are gratefully for the comments of two anonymous reviewers that improved the original manuscript.

Edited by: N. Basu

\section{References}

Batjes, N. H.: SOTER-based soil parameter estimates for Southern Africa (ver. 1.0), Report 2004/04, ISRIC - World Soil Information, Wageningen, 2004.

Benito, G., Rohde, R., Seely, M., Külls, C., Dahan, O., Enzel, Y., Todd, S., Botero, B., Morin, E., Grodek, T., and Roberts, C.: Management of Alluvial Aquifers in Two Southern African Ephemeral Rivers: Implications for IWRM, Wat. Resour. Manage., 24, 641-667, doi:10.1007/s11269-009-9463-9, 2009.

Benito, G., Thorndycraft, V. R., Rico, M. T., Sánchez-Moya, Y., Sopeña, A., Botero, B. A., Machado, M. J., Davis, M., and PérezGonzález, A.: Hydrological response of a dryland ephemeral river to southern African climatic variability during the last millennium, Quatern. Res., doi:10.1016/j.yqres.2011.01.004, in press, 2011.

Beran, M., Hosking J. R. M., and Arnell, N.: Comment on "Two-Component Extreme Value Distribution for Flood Frequency Analysis" by Fabio Rossi, Mauro Fiorentino and Pasquale Versace, Water Resour. Res., 22(2), 263-266, doi:10.1029/WR022i002p00263, 1986.

Dahan, O., McDonald, E. V., and Young, M. H.: Flexible time domain reflectometry probe for deep vadose zone monitoring, Vadose Zone J., 2, 270-275, doi:10.2113/2.2.270, 2003.

Dahan, O., Tatarsky, B., Enzel, Y., Külls, C., Seely, M., and Benito, G.: Dynamics of flood water infiltration and ground water recharge in hyperarid desert, Ground Water, 46, 450-461, doi:10.1111/j.1745-6584.2007.00414.x, 2008.

England Jr., J. F.: Probabilistic extreme flood hydrographs that use paleoflood data for dam safety applications, Flood Hydrology Group, Bureau of Reclamation, Technical Service Center, Denver, Colorado, 29 pp., 2003.

Enzel, Y. and Wells, S. G.: Extracting Holocene paleohydrology and paleoclimatology information from modern extreme flood events: An example from southern California, Geomorphology, 19, 203-206, 1997.

Fersch, B.: Interactions between riparian phreatophytes and alluvial aquifers, Diplomarbeit am Institut fur Hydrologie, Universität Freiburg, Germany, 2007.

Francés, F.: Flood frequency analysis using systematic and nonsystematic information, in: Systematic, palaeoflood and historical data for the improvement of flood risk estimation, edited by: Benito, G. and Thorndycraft, V. R., CSIC, Madrid, 55-70, 2004.

Francés, F., Salas, J. D., and Boes, D. C.: Flood frequency analysis with systematic and historical or paleoflood data based on the two-paramater general extreme value models, Water Resour. Res., 30, 1653-1664, 1994.

Francés, F., Velez, J. I., and Velez J. J.: Split-parameter structure for the automatic calibration of distributed hydrological models, J. Hydrol., 332, 226-240, doi:10.1016/j.jhydrol.2006.06.032, 2007.
Greenbaum, N., Schwartz, U., Schick, A. P., and Enzel, Y.: Palaeofloods and the estimation of long-term transmission losses and recharge to the Lower Nahal Zin alluvial aquifer, Negev Desert, Israel, in: Ancient floods, modern hazards: Principles and applications of Paleoflood Hydrology, edited by: House P. K., Webb R. H., Baker V. R., Levish D. R., American Geophysical Union, Washington DC, Water Sci. Appl., 5, 311-328, 2002.

Hoffman, M. T. and Rohde, R. F.: Rivers through time: Historical changes in the riparian vegetation of the semi-arid, winter rainfall region of South Africa in response to climate and land use, J. Hist. Biol., 44(1), 59-80, doi:10.1007/s10739-010-92464, 2011.

Hydrologic Engineering Center: HEC-RAS, River Analysis System, Hydraulics Reference Manual, CPD-69, US Army Corps of Engineers, Davis, California, 1995.

Kelso, C. and Vogel, C.: The climate of Namaqualand in the nineteenth century, Climatic Change, 83, 357-380, doi:10.1007/s10584-007-9264-1, 2007.

Knighton, A. D. and Nanson, G. C.: Distinctiveness, diversity and uniqueness in arid zone river systems, in: Arid Zone Geomorphology, edited by: Thomas, D. S. G., Wiley, Chichester, 185203, 1997.

Lang, M., Ouarda, T. B. M. J., and Bobée, B.: Towards operational guidelines for over-threshold modeling, J. Hydrol., 225, 103-117, 1999.

Marais, J. A. H.: Updated Technical Report on the Spektakel Water Scheme in the District of Springbok, Cape Provincem Unpublished report on the O'Okiep Copper Company Limited, South Africa, Nababeep, South Africa, 1981.

Marais, J. A. H., Agenbacht, A. L. D., Prinsloo, M., and Basson, W. A.: The Geology of Sprinbok Area, Explanation: Sheet 2916. Scale 1:250 000, Council for Geoscience, Pretoria, South Africa, 103 pp., 2001.

Matlock, W. G. and Davis, R. P.: Groundwater in the Santa Cruz Valley, Arizona, Technical Bulletin, 194, University of Arizona, Agricultural Experiment Station, Tucson, 37 pp., 1972.

Midgley, G. F. and Thuiller, W.: Could anthropogenic climate change threaten biodiversity in Namaqualand?, J. Arid Environ., 70, 615-628, doi:10.1016/j.jaridenv.2006.11.020, 2007.

Midgley, G. F., Chapman, R. A., Hewitson, B., Johnston, P., De Wit, M., Ziervogel, G., Mukheibir, P., Van Niekerk, L., Tadross, M., Van Wilgen, B.W., Kgope, B., Morant, P., Theron, A., Scholes, R. J., and Forsyth, G. G.: A Status Quo, Vulnerability and Adaptation Assessment of the Physical and Socio-Economic Effects of Climate Change in the Western Cape, Report to the Western Cape Government, Cape Town, South Africa, Stellenbosch, CSIR, Report No. ENV-S-C 2005-073, 2005.

Milly, P. C. D., Dunne, K. A., and Vecchia, A. V.: Global pattern of trends in streamflow and water availability in a changing climate, Nature, 438, 347-350, doi:10.1038/nature04312, 2005.

Morin, E., Grodek, T., Dahan, O., Benito, G., Kulls, C., Jacoby, Y., Van Langenhove, G., Seely, M., and Enzel, Y.: Flood routing and alluvial aquifer recharge along the ephemeral arid Kuiseb River, Namibia, J. Hydrol., 368, 262-275, doi:10.1016/j.jhydrol.2009.02.015, 2009.

Redmond, K. T., Enzel, Y., House, P. K., and Biondi, F.: Climate variability and flood frequency at decadal to millennial time scales, in: Ancient floods, modern hazards: Principles and applications of Paleoflood Hydrology, edited by: House P. K., Webb 
R. H., Baker V. R., and Levish D. R., American Geophysical Union, Washington DC, Water Sci. Appl. 5, 21-45, 2002.

Reid, I., Laronne, J. B., and Powell, D. M.: The Nahal Yatir bedload database: sediment dynamics in a gravel-bed ephemeral stream, Earth Surf. Process. Landf., 20, 845-857, 1995.

Reynolds, J. F., Smith D. M. S., Lambin E. F., Turner, II, B. L., Mortimore, M., Batterbury, S. P. J., Downing, T. E., Dowlatabadi, H., Fernández, R. J., Herrick, J. E., HuberSannwald, E., Jiang, H., Leemans, R., Lynam, T., Maestre, F. T., Ayarza, M., and Walker, B.: Global Desertification: Building a Science for Dryland Development, Science, 316, 847-851, doi:10.1126/science.1131634, 2007.

Rimon, Y., Dahan, O., Nativ, R., and Geyer, S.: Water percolation through the deep vadose zone and groundwater recharge: preliminary results based on a new vadose zone monitoring system, Water Resour. Res., 3, W05402, doi:10.1029/2006WR004855, 2007.
Rohde, R., Hoffman, T., Waldeck, D., and Boyce, A. M.: Flood Events in the Buffels River - an internal WADE Report, Unpublished, Institute for Plant Conservation, University of Cape Town, Rondebosch, South Africa, 5 pp. 2005.

Seely, M. K., Buskirk, W. H., Hamilton, W. J. I., and Dixon, J. E. W.: Lower Kuiseb River perennial vegetation survey, Journal of the South West Africa Scientific Society, 35, 57-86, 1981.

Shentsis, I. and Rosenthal, E.: Recharge of aquifers by flood events in an arid region, Hydrol. Process., 17, 695-712, doi:10.1002/hyp.1160, 2003.

Stedinger, J. R. and Cohn, T. A.: Flood frequency analysis with historical and paleoflood information, Water Resour. Res., 22, 785-793, 1986.

Tooth, S.: Process, form and change in dryland rivers: a review of recent research, Earth Sci. Rev., 51, 67-107, doi:10.1016/S00128252(00)00014-3, 2000. 